\title{
Species composition and WNV screening of mosquitoes from lagoons in a wetland area of the Algarve, Portugal
}

\author{
Ferdinando B. Freitas ${ }^{1}$, Maria Teresa Novo ${ }^{1}$, Aida Esteves ${ }^{2}$ and A. Paulo G. de Almeida ${ }^{1}$ * \\ ' Unidade Ensino e Investigação de Parasitologia Médica/Unidade de Parasitologia e Microbiologia Médica, Instituto de Higiene e Medicina Tropical, \\ Universidade Nova de Lisboa, Lisboa, Portugal \\ ${ }^{2}$ Unidade Ensino e Investigação de Microbiologia Médica/Unidade de Parasitologia e Microbiologia Médica, Instituto de Higiene e Medicina Tropical, \\ Universidade Nova de Lisboa, Lisboa, Portugal
}

Edited by:

Rubén Bueno-Marí, University of Valencia, Spain

Reviewed by:

Ying Xu, West Virginia University, USA

Olga Papadodima, National Hellenic

Research Foundation, Greece

Carles Aranda, Consell Comarcal del

Baix Llobregat, Spain

${ }^{*}$ Correspondence:

A. Paulo G. de Almeida, Unit of Medical Parasitology/Unidade de

Parasitologia e Microbiologia Médica,

Instituto de Higiene e Medicina

Tropical, Universidade Nova de

Lisboa, Rua da Junqueira, 100,

1349-008 Lisboa, Portugal.

e-mail: palmeida@ihmt.unl.pt
The aim of this study was to evaluate mosquito abundance, species diversity, larval and adult population dynamics in seven lagoons integrated in the wetland coastal system of the Algarve, Portugal, in the summer of 2007, as well as the screening of these for West Nile virus (WNV). WNV has been isolated from mosquitoes in this region, in the summer of 2004, next to the putative area of infection of two linked human WN cases. Adult mosquitoes were collected with $\mathrm{CDC}$ traps baited with $\mathrm{CO}_{2}$, and potential breeding sites were surveyed for immature stages. Morphological identification of 1,432 adult mosquitoes and 85 larvae revealed the presence of 10 species: Anopheles atroparvus, Anopheles algeriensis, Coquillettidia richiardii, Culex modestus, Culex pipiens, Culex theileri, Culex univittatus, Culiseta longiareolata, Aedes caspius, and Aedes detritus. Adult mosquito peak densities were recorded in July, contrasting with null larval breeding in the same month in the surveyed biotopes. Most abundant species were C. pipiens (52\%), C. theileri (29\%), and A. caspius (11\%). Lagoon Salgados and Quinta das Salinas, exhibited the highest similarity of culicid fauna, despite being most distant from each other, Female mosquitoes $(1,249$ specimens) screened by RT-PCR, did not reveal WNV products. However, previous detection of WNV activity in this area, susceptible to re-introductions, demands for continued vigilance.

Keywords: mosquitoes, wetlands, ecology, surveillance, WNV, Portugal

\section{INTRODUCTION}

Mosquitoes act as vectors in the transmission of human diseases, such as several arboviruses belonging to the genera Alphavirus, Flavivirus, and Bunyavirus (Lundström, 1999). West Nile virus (WNV) currently the most widely distributed arbovirus in the world, occurring on all continents except Antarctica, has been reported to occur in mosquitoes and to infect human and other vertebrates (Kramer et al., 2008). This virus was first isolated from the blood of a sick woman in the West Nile District of Uganda in 1937 (Smithburn et al., 1940).

In recent years human or animal, mainly enzootics involving horses, WNV disease in the Eastern Hemisphere have been reported mostly from areas in the Mediterranean Basin: in Algeria in 1994, Morocco in 1996 and 2003, Tunisia in 1997 and 2003, Romania in 1996 through 2000, Czech Republic in 1997, Israel in 1999 and 2000, Russia in 1999-2001 and 2003-2007, Hungary 2003-2008, southern France in 2000, 2003-2004, Italy in 1998, 2008-2009, Spain in 2008-2009, and Greece 2010-2011 (Murgue et al., 2001; Zeller and Schuffenecker, 2004; Hayes et al., 2005; Krisztalovics et al., 2008; Rossini et al., 2008; Barzon et al., 2009; Rizzo et al., 2009; Chaskopoulou et al., 2011; Danis et al., 2011a,b; Vázquez et al., 2011).

In Portugal epidemiologic surveys for West Nile detection in human and animal populations have been carried out since the 1970s revealing seroreactivity for this virus. However, the first WNV isolation from mosquitoes was reported in 1971 (Filipe,
1972). In the summer 2004 two linked WNV cases were reported in Irish tourists, acquired in the Algarve (Connell et al., 2004) after which WNV was isolated from mosquitoes in the same region (Esteves et al., 2005).

Throughout its worldwide distribution, WNV is maintained in nature by enzootic cycles between ornithophilic mosquitoes, predominantly Culex species, although other genera may also be vectors, and birds (Hayes et al., 2005). Mosquitoes can also act as bridge vectors transmitting WNV out of its natural cycle to accidental hosts, such as domestic animals, particularly horses, and humans (Rappole and Hubálek, 2003; Linke et al., 2007; Kramer et al., 2008).

There are two important periods for pathogen introduction that correspond to the biannual bird migration. The first, during spring, when birds fly from Africa and can introduce pathogens in the North hemisphere especially in Mediterranean wetlands as well as in other countries from Europe. The second period, in autumn, when birds return to Africa, may carry pathogens from Northern to Southern Europe (Jourdain et al., 2007). WNV has been isolated from actively migrating birds (Malkinson et al., 2002). In European regions WNV cases occur in late summer and early fall months, when mosquito populations are at their highest densities. WNV outbreaks have occurred at urban sites near wetlands where migratory birds, mosquitoes, and humans are concentrated (Rappole et al., 2000). 
Climate changes can influence significantly vector-borne disease transmission, as insects are very sensitive to meteorological conditions, namely temperature and humidity. Warmer weather and high precipitation may lead to sudden increases of mosquito populations, due to abundant larval habitats and climatic favorable conditions. Warmer weather would also influence people's behavior, leading them to spend more time outdoors. Outdoor activities, associated or not with tourism, can lead to higher exposure of humans to mosquito bites, and consequently to the transmission of mosquito borne diseases (Morgan, 2006). The ecological understanding of mosquito vectors of arboviruses is an important contribution of the surveillance regarding the risks for public health and mosquito control programs (White, 2001; Rydzanicz and Lonc, 2003; Medlock et al., 2006).

Due to its geographic localization and favorable climate, the Algarve province combines several conditions that can lead to the emergence and re-emergence of mosquito borne diseases. The presence of wetlands and lagoons, used by migratory birds can favor new viral introductions and the presence and abundance of mosquito populations can maintain viral enzootic cycles. This kind of water collections provide suitable breeding sites to some mosquito species reported as vectors of WNV (Medlock et al., 2006). The Algarve is a well known touristic place, with thousands of visitors every year.

The goals of our study included the study of the abundance and diversity of mosquitoes in the vicinity of several water collections, lagoons, of the Algarve used by migratory birds, as well as screening those mosquitoes for the presence of WNV.

\section{MATERIALS AND METHODS STUDY AREA}

The study took place during the summer months of 2007, from June to September, in seven lagoons near the coastal line, in the province of the Algarve, southern Portugal, next to four localities, within a maximum distance of $30 \mathrm{~km}$ (Figure 1): (1, a) Lagoon Salgados (N37 $5^{\prime} 53.33^{\prime \prime}$; W $\left.8^{\circ} 20^{\prime} 3.61^{\prime \prime}\right)$, Pêra; (2, b) Lagoon Nova $\left(\mathrm{N} 37^{\circ} 5^{\prime} 29,78^{\prime \prime}\right.$; $\left.\mathrm{W} 8^{\circ} 8^{\prime} 33,28^{\prime \prime}\right)$ and $(2, \mathrm{c})$ Lagoon Antiga (N37 $5^{\prime} 48.03^{\prime \prime}$; W8 $\left.8^{\circ} 8^{\prime} 57.98^{\prime \prime} \mathrm{W}\right)$, Vilamoura Natural Park, Vilamoura; (3, d) Lagoon Almargem (N37 $6^{\prime} 8,07^{\prime \prime}$; W8 $\left.21^{\prime} 15.97^{\prime \prime}\right)$, Quarteira; (4, e) Lagoon Dunas Douradas (N37 $2^{\prime} 42,6^{\prime \prime}$; W8 $3^{\circ} 8,4^{\prime \prime}$; (3, f) Lagoon Garrão (N37 $2^{\prime} 42,6^{\prime \prime}$; $\left.\mathrm{W} 8^{\circ} 2^{\prime} 32,6^{\prime \prime}\right)$ and Quinta das Salinas (N $37^{\circ} 2^{\prime} 15,1^{\prime \prime}$; W $8^{\circ} 2^{\prime} 1,3^{\prime \prime}$; (3, g) Garrão.

Some of these lagoons are referenced as regions of high diversity of wildlife including the presence of more than a hundred bird species. Due to this, and in particularly the Salgados lagoon was included in the national IBA's (PT035 Important Bird Area $149 \mathrm{ha}$ ) being one of the more important wetlands in the Algarve, gaining national, and even international, interest, for some bird species, such as the Porphyrio porphyrio (Purple Swamphen) and Aythya nyroca (Ferruginous Duck; CCDR, 2007).

Algarve provides a wide range of outdoor activities, namely bird watching, fishery, aquaculture, and salt-works. Climate in the Algarve may be considered Mediterranean Csa type according to the Köppen-Geiger classification. For the interval 19712000 , monthly average temperature varies from $16^{\circ} \mathrm{C}$ in JanuaryDecember to $28^{\circ} \mathrm{C}$ in July-August (mean average $17^{\circ} \mathrm{C}$, maximum

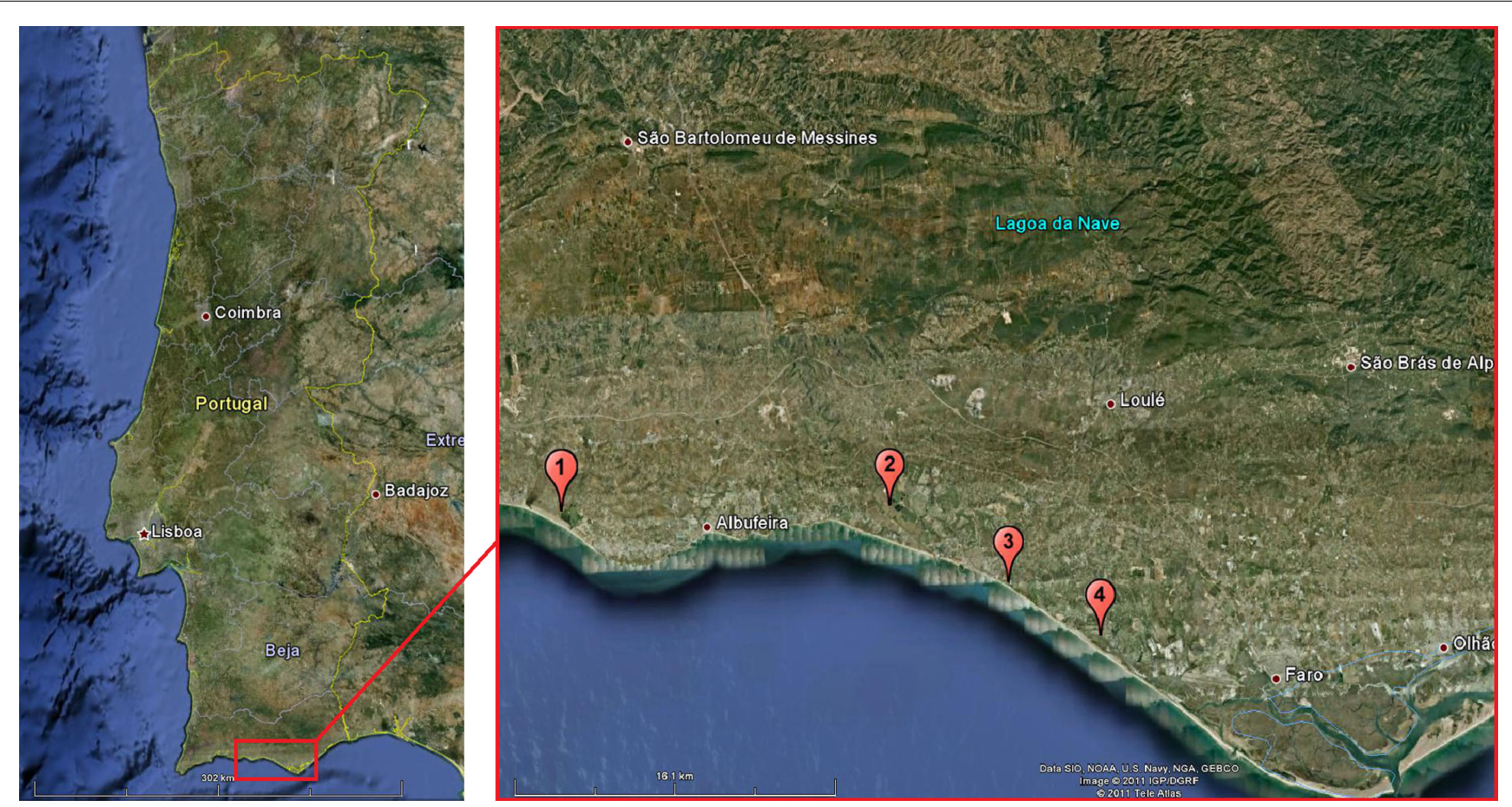

FIGURE 1 | Map showing the localization of the study area and the various surveyed lagoons: (1, a) Lagoon Salgados (Pêra); $(2$, b) Lagoon Nova, (2, c) Lagoon Antiga (Parque ambiental de Vilamoura); (3, d)
Lagoon Almargem (Quarteira); (4, e) Lagoon Dunas Douradas, (4, f) Lagoon Garrão, and (4, g) Lagoon Quinta das Salinas (Garrão). Distance between 1 and 4 is ca. $30 \mathrm{~km}$. 
average $21^{\circ} \mathrm{C}$, minimum average $12^{\circ} \mathrm{C}$ ), and mean precipitation varies from $2.1 \mathrm{~mm}$ in August to $96 \mathrm{~mm}$ in December (IM, 2010).

\section{MOSQUITO SAMPLING AND PROCESSING}

Adult mosquitoes were collected monthly in the seven lagoons above, in fixed sampling sites with CDC (Centers for Disease Control; Sudia and Chamberlain, 1962) baited with carbon dioxide $\left(\mathrm{CO}_{2}\right.$; ca. $1 \mathrm{~kg} /$ trap; Newhouse et al., 1966), operating overnight from before dusk to after the sunrise (minimum $12 \mathrm{~h}$ ). All traps were suspended at a height of 1.5-2 $\mathrm{m}$ from the ground, either in trees or human-made structures by the edge of the lagoons. Collected mosquitoes were transported live in refrigerated boxes to laboratory where they were frozen till identification.

Fixed potential breeding sites were surveyed for mosquito larvae and pupae using a standard dipper $(\mathrm{ca} .700 \mathrm{ml})$, performing a minimum of five dips per site $(3500 \mathrm{ml})$. These included margins of the lagoons, or irrigation ditches and effluents from urban wastewater treatment plants (UWTP) that discharged to the lagoons. Physical and chemical parameters (temperature, oxygen, $\mathrm{pH}$, ion concentration, conductivity, total dissolved solids, salinity, and water depth) of the water were recorded. Whenever it was not possible to prospect the fixed breeding site (for example, when it was dry), an attempt was made to survey the vicinity. Immature forms were transported to the laboratory in glycerinated ethanol $(4 \%, \mathrm{~V} / \mathrm{V})$. Physical and chemical parameters of the water collections are presented as their mean values, during the observation period, for each of these lagoons.

Adult mosquitoes were sorted by site, species, sex, and females by the gonotrophic stage, pooled accordingly to a maximum of 50 specimens per pool, and kept at $-80^{\circ} \mathrm{C}$ until viral screening. Immatures were mounted in Ribeiro medium (Ribeiro, 1967). Adults and immatures were identified according to identification keys by Ribeiro and Ramos (1999).

Adult mosquito densities were calculated as mean mosquitoes per trap-night. The modified Sorensen coefficient (Southwood, 1978), grouped the surveyed lagoons according to the similarity of their adult culicid fauna, generating a respective dendrogram. Breeding site index $(\mathrm{R})$ was calculated as the number of biotopes they were positive for culicids (Ribeiro et al., 1980), and larval density was calculated as the mean number of larvae per dipper.

\section{VIRAL SCREENING}

Adult mosquitoes were triturated on a vibrator for $30 \mathrm{~s}$ with glass beads and alundum in a $15-\mathrm{ml}$ conical, screw cap plastic tube with $1.5 \mathrm{ml}$ of phosphate-buffered saline (PBS) containing bovine serum albumin (BSA) at $4 \%(\mathrm{~W} / \mathrm{V})$. All the tubes were kept on ice. After a centrifugation $(896 \times \mathrm{G})$ at $4^{\circ} \mathrm{C}$ for $10 \mathrm{~min}$ three aliquots were made, using sterile pipettes, to be used on Reverse transcriptase - polymerase chain reaction (RT-PCR). RT-PCR reactions were performed using $6 \mu \mathrm{l}$ of RT buffer, $2 \mu \mathrm{l}$ of $0.1 \mathrm{M}$ dithiothreitol, $1 \mu$ l RNA guard, $5 \mu$ dNTP's $(2.5 \mathrm{mM}), 2.5 \mu l$ random primer

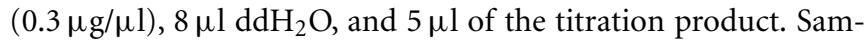
ples were boiled for $5 \mathrm{~min}$ and cooled on ice. To this mixture it was added $1 \mu \mathrm{l}$ of Moloney murine leukemia virus (MMLV) reverse transcriptase. The reaction was performed at $37^{\circ} \mathrm{C}$ for $60 \mathrm{~min}$, with a final step of $95^{\circ} \mathrm{C}$ for $10 \mathrm{~min}$.
Following reverse transcriptase, $5 \mu \mathrm{l}$ of cDNA was transferred to $45 \mu \mathrm{l}$ of a PCR mix containing $5 \mu \mathrm{l}$ Taq buffer, $1.75 \mu \mathrm{l}$

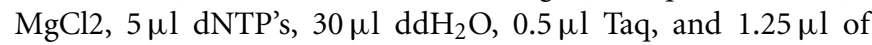
each primer, cFD2 (5'-GTGTCCCAGCCGGCGGTGTCATCAGC$\left.3^{\prime}\right)$ and MAMD ( $5^{\prime}$-AACATGATGGGRAARAGRGARAA-3') in the first round (Scaramozzino et al., 2001) and FS 788M (Esteves et al., 2005) for the second. The thermal cycling profile consisted on $15 \mathrm{~min}$ at $94^{\circ} \mathrm{C}$, three initial cycles of $60 \mathrm{~s}$ at $94^{\circ} \mathrm{C}, 60 \mathrm{~s}$ at $52^{\circ} \mathrm{C}$, and $60 \mathrm{~s}$ at $72^{\circ} \mathrm{C}$, followed by 40 cycles of $30 \mathrm{~s}$ at $94^{\circ} \mathrm{C}, 30 \mathrm{~s}$ at $56^{\circ} \mathrm{C}$, and $30 \mathrm{~s}$ at $72^{\circ} \mathrm{C}$. The amplifications products were analyzed on agarose gels ( 1.5 or $2 \%$ for a better resolution) containing ethidium bromide.

\section{RESULTS}

\section{ADULTS}

A total of 1,432 adult mosquitoes were caught in the seven surveyed lagoons, between June and September 2007. Mosquito abundance, mean mosquito density per CDC trap, was lowest in June and maximum in July, coinciding with the highest mean temperatures and lowest precipitation recorded for the area (Figure 2).

Eight species were collected as adult mosquitoes: Anopheles (Anopheles) algeriensis $(n=14)$, Aedes (Ochlerotatus) caspius $(n=152)$, Aedes (Ochlerotatus) detritus s.l. $(n=7)$, Coquillettidia richiardii $(n=20)$, Culex (Culex) pipiens $(n=749)$, Culex (Culex) theileri $(n=415)$, Culex (Culex) univittatus $(n=51)$, and Culiseta (Allotheobaldia) longiareolata $(n=24)$, The most abundant was C. pipiens (52\%), which peaked in July, as did A. caspius, the third most common species (11\%). However, C. theileri (29\%), the second most abundant mosquito, exhibited a slow increase, peaking in August, but maintaining similar levels from July to September. Relative mosquito species densities varied among the seven surveyed lagoons (Figure 3). The dendrogram based on the modified Sorensen coefficient (Southwood, 1978), grouped the surveyed lagoons according to the similarity of their culicid fauna (Figure 4).

\section{IMMATURES}

Collection of immature forms in the margins of the seven surveyed lagoons, irrigation ditches and UWTP effluents draining

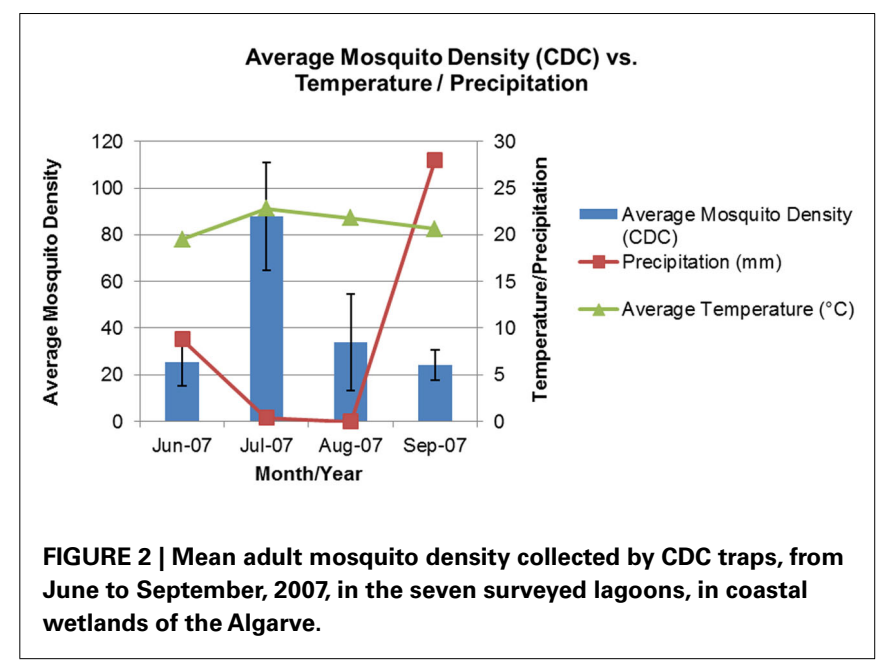




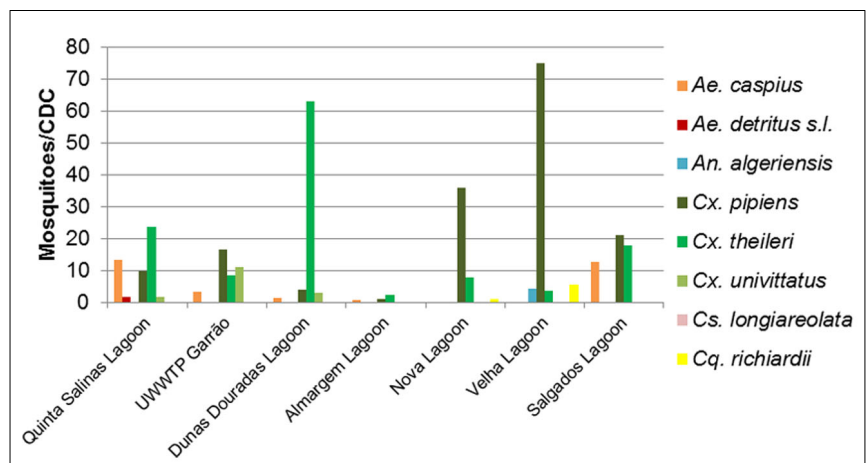

FIGURE 3 | Mean adult mosquito species composition of the seven surveyed lagoons in the wetlands of the Algarve collected by CDC traps, from June to September, 2007.

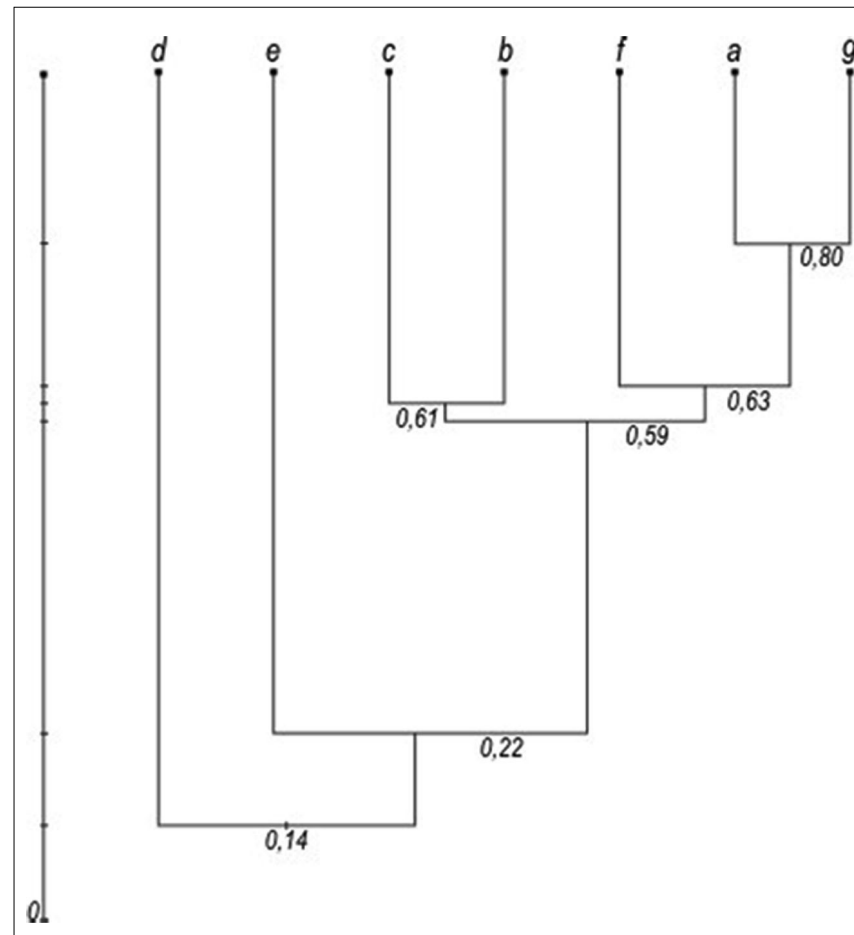

FIGURE 4 | Dendrogram based on the modified Sorensen coefficient of similarity between the surveyed lagoons: (a) Salgados (1), (b) Nova (2), (c) Antiga (2), (d) Almargem (3), (e) Dunas Douradas (4), (f) Garrão (4), and (g) Quinta das Salinas (4), (numbers in brackets refer to Figure 1).

to these, in a minimum of 7 and a maximum of 15 biotopes, yielded a total of 85 larvae, with negative collections in the month of July, and a breeding index (R) of $0.2-0.25$ in the remaining months (Figure 5). Mean larval density was 0.18 larvae/dipper in June, 0.25 in August, and 0.7 in September. Six species were collected as immatures, Anopheles (Anopheles) atroparvus, A. caspius, Culex (Barraudius) modestus, C. Pipiens, and C. theileri, which varied according to the month (Figure 6), but also according to the nature of the biotope of collection (Figure 7). Physical and chemical parameters of these water collections are presented as

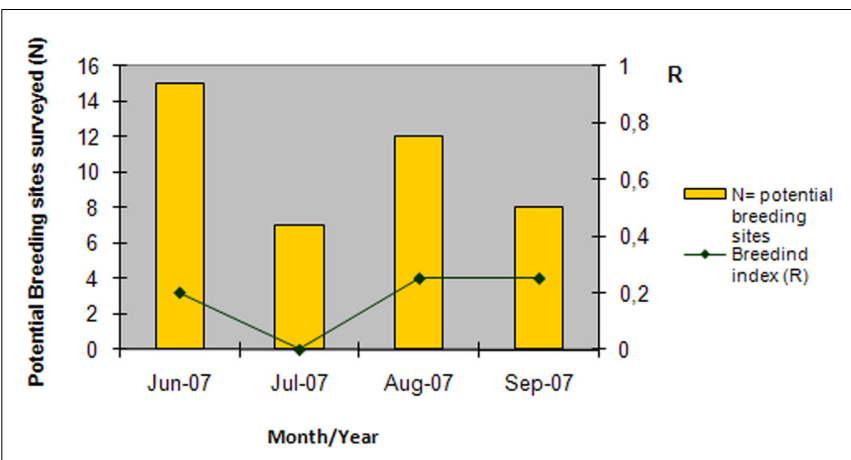

FIGURE 5 | Potential breeding sites surveyed for immature culicids along the seven lagoons surveyed, and respective breeding index, from June to September 2007.

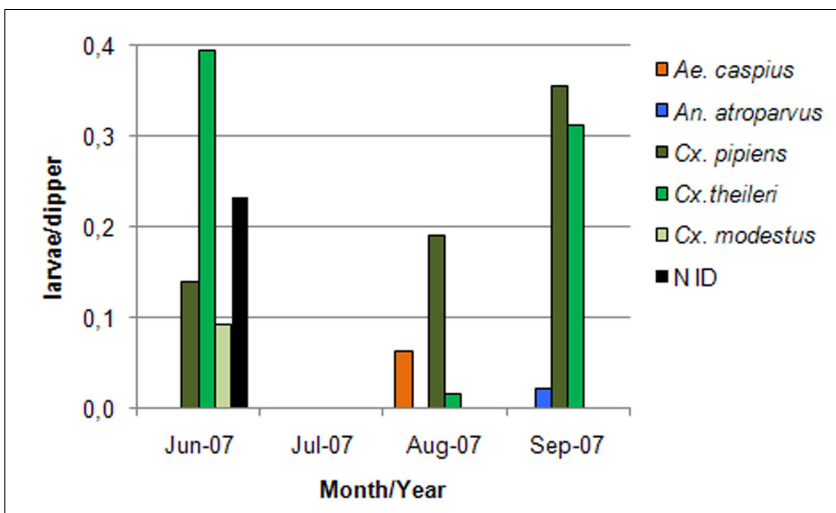

FIGURE 6 | Species composition and density (mean larvae/dipper) of the culicid immature forms collected along the lagoons surveyed. $A$ total of 85 larvae were collected. No larvae were collected in the margins of natural lagoons.

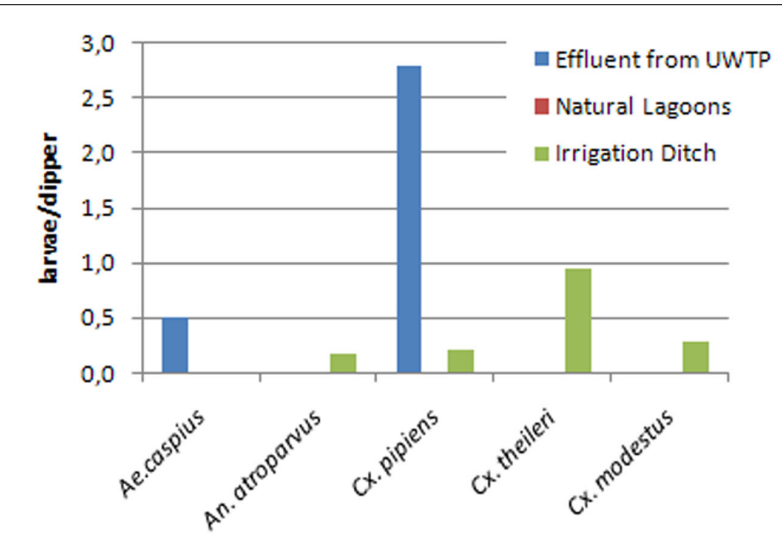

Species collected

FIGURE 7 | Culicid immature species, and relative density, according to the nature of the biotope, in the surveyed lagoons.

their mean values, during the observation period, for each of these lagoons (Table 1). 
Table 1 | Physical and chemical parameters* of the seven lagoons surveyed, communication with sea water and effluents of urban wastewater treatment plants, represented as the mean value for the observational period.

\begin{tabular}{|c|c|c|c|c|c|c|c|c|c|}
\hline Lagoon & Sea water & UWTP & $\mathbf{p H}$ & Redox potential (mV) & Conductivity $(\mu \mathrm{S} / \mathrm{cm})$ & TDS (mg/l) & Salinity (ppt) & $\mathrm{O}_{2} \mathrm{mg} / \mathrm{l}$ & $\mathbf{T}^{\circ} \mathbf{C}$ \\
\hline Nova $(2, b)$ & - & Yes & 7.98 & -66.33 & $2,645.67$ & $1,590.67$ & 1.62 & 9.99 & 27.08 \\
\hline Almargem $(3, d)$ & Yes & Yes & 8.05 & -73.00 & $5,015.00$ & $3,495.00$ & 11.15 & 9.39 & 26.03 \\
\hline D. Douradas $(4, e)$ & - & Yes & 8.38 & -96.67 & $1,396.00$ & 832.67 & 0.87 & 9.38 & 28.00 \\
\hline Garrão $(4$, f) & - & Yes & 7.62 & -50.00 & $1,852.00$ & $1,109.00$ & 1.17 & 9.02 & 23.70 \\
\hline
\end{tabular}

The higher salinity values recorded are represented in bold.

*Water physical and chemical parameters were measured at about 12:00 a.m.

In brackets are the numbers referring to Figure 1 and the letters referring to Figure 4.

\section{VIRAL SCREENING}

A total of 1,249 female mosquitoes were screened for WNV (89\% of the total collection), of which $55 \%(n=687)$ were C. pipiens, 31.8\% $(n=397)$ C. theileri, $6.7 \%(n=84)$ A. caspius, $3.8 \%$ $(n=47)$ C. univittatus, $1.6 \%(n=20)$ C. Richiardii, and $1.1 \%$ $(n=14)$ A. algeriensis. However, there was no detection of WNV nucleic acid sequences.

\section{DISCUSSION}

This survey for mosquitoes along seven lagoons located along the coastal line of the Algarve evidenced a seasonal dynamic of adults, following a typical pattern accompanying the mean temperature, with highest densities in the hottest summer months for temperate climates (Lysyk, 2010). This is not always the case as sometimes, due to low atmospheric humidity related with continued lack of precipitation, density decreases can be observed. C. pipiens was the most abundant species, accounting for nearly half of the collections, peaking in July, as did A. caspius, the third most common species. This seasonal dynamics contrasts with that registered in this area the previous year (2006), when A. caspius had been the dominant species, peaking in July-August, and C. pipiens exhibited a decrease in these months (Osório et al., 2008), despite the sampling method being also CDC traps, thus comparable to that used in this study. Another contrasting difference in our study, in 2007, was that $C$. theileri was the second most abundant species, exhibiting a slow increase and peaking in August. This also contrasts with previous findings by us, where $C$. theileri came only to fifth most common species in this same area (Almeida et al., 2008).

Diversity, similarity and relative abundance of mosquito species varied among the surveyed lagoons. Salgados $(1, a)$ and Quinta das Salinas $(4, \mathrm{~g})$ exhibited similarly medium densities of $C$. pipiens, $C$. Theileri, and A. caspius, thus having higher Sorensen coefficients of similarity and coming closer in the dendrogram. These lagoons exhibited the highest salinity values (bold values in Table 1), together with Almargem lagoon $(3, \mathrm{~d})$, thus it is not surprising that these were where A. caspius, a halophile species, had higher densities, and was also found as immature forms. Almargem lagoon was dissimilar to these due to its very low mosquito density. The lagoons at Vilamoura natural park, Nova $(2, \mathrm{~b})$, and Antiga $(2, \mathrm{c})$, were very identical between each other but different from the previous, in that $C$. pipiens was the predominating species, followed closely by Garrão $(4, \mathrm{f})$, though with much lesser abundances. These three lagoons are those closer to UWTPs which can account for that predominance of $C$. pipiens and relative similarity. Dunas Douradas $(4, \mathrm{e})$ exhibited a quite different culicid fauna, with $C$. theileri as the overly dominant species, thus placing it far apart from the others. However, the total small sample size may have affected the outcome of this diversity analysis.

Comparing the species collected in different life stages, two were not caught as adults but only as larvae, $A$. atroparvus and $C$. modestus, whereas five were not caught as immatures, namely A. algeriensis, $A$. detritus s.l., C. univittatus, C. Richiardii, and C. longiareolata. Furthermore, no relation could be established between species collected in both life stages in each lagoon site. A. atroparvus was not caught as adult, likely due to the collection method used, as this species rarely is attracted to CDC traps, and is mainly found in indoor resting collections (Almeida et al., 2008). C. modestus was not caught as adult probably due to its low abundance, as shown in previous surveys of this very same region, where only two, also immature forms, were caught in 1975 (Ramos et al., 1977/1978), in similarly brackish waters as in this study, or not caught at all as adults in later surveys (Ramos et al., 1992; Almeida et al., 2008). Still, this species is a known vector of WNV in the Mediterranean area (Mouchet et al., 1970).

Immature surveys were mostly negative, with breeding indexes of $0.2-0.25$, and, when positive, yielded very few specimens, which may account for the smaller number of species collected in relation to adults. The type of biotopes surveyed, which might not be the preferred ones, may also justify the lesser representation of species as immature stages. The particular bioecology of $C$. richiardii, whose immature stages live attached to stems of aquatic vegetation, requiring special techniques for their collection, is also a likely justification for their absence in immature collections, despite their continued presence as adults in these lagoonal ecosystems (Almeida et al., 2005, 2008). The low level of precipitation, along with increased evaporation, during the summer months, with the consequent decrease in water level and some degree of eutrophication, can be a possible explanation for the low breeding indexes registered. As to the physic-chemical parameters of the water, a pH higher than expected $(>8.2)$ was detected in Salgados and Dunas Douradas lagoons, although this did not reveal to be exclusive of mosquito larval presence, as these were detected 
in Salgados, which had the highest $\mathrm{pH}$ registered. The levels of dissolved oxygen measured were always above $5 \mathrm{mg} / \mathrm{l}$, at around noon time, which could indicate much lower levels in the night and dawn as observed in this coastal system (Newton et al., 2010). Furthermore, in the lagoons Garrão and Dunas Douradas, the ichthyofauna was inexistent in 2007 probably due to anoxia in the water and lack of communication with the sea, and high mortality was observed in the Salgados lagoon (CCDR, 2007). Thus, if on one hand, conditions for the presence of mosquito larvae in the waters of these lagoons, do not seem to be very favorable, on the other hand, if colonization by mosquito immatures happened, it could be difficult to be naturally controlled due to the absence of fish, and other, natural predators, such as coleoptera and ephemeroptera, which have also very low densities, or are totally absent, in these lagoons (CCDR, 2007).

It is also noteworthy the presence of immature culicids and their species in relation to the nature and site of the biotope. First and foremost, no larvae were found in the margins of any of these lagoons, but only in the ditches discharging to them. In irrigation ditches C. theileri, C. modestus, C. Pipiens, and A. atroparvus could be found in progressively lower densities, whereas $A$. caspius was found just in UWTP effluents. $C$. pipiens was the only species that was found in both biotopes, however, with much higher densities in the effluents from UWTP, clearly illustrating the capacity of this species to breed in somewhat polluted waters.

Algarve is known to be one of the most touristic places of Portugal, with activities that include bird watching. Some of these lagoons are referenced as bird sanctuaries, with more than a hundred species registered. On the other hand, some of the birds regularly seen in these lagoons, such as Anas platyrhynchos (Mallard) in Salgados, Hirundo rustica (Barn Swallow), and Pandion haliaetus (Osprey) in Garrão, have been found infected with arboviruses such as WNV (CDC, 2011). Some studies also reported the presence of neutralizing antibodies against WNV in birds from Portugal like Buteo buteo (Common Buzzard), Falco tinnunculus (Common Kestrel), and Ciconia ciconia (White Stork) among others (Formosinho et al., 2006), and in other Mediterranean countries like the Turdus merula (blackbirds) and Passer domesticus (house sparrows; Figuerola et al., 2008). Furthermore, some of the bird species found in Portugal like A. platyrhynchos (Mallard), Anas querquedula (Garganey), Ardea purpurea (Purple Heron) are referenced as migratory, thus presenting the risk of pathogen introduction. (Feith, 2007, 2010; Jourdain et al., 2007).

Mosquito species found in this survey, such as $A$. atroparvus, $A$. caspius, $A$. detritus s.l., C. richiardii, C. pipiens, C. theileri, C. modestus, and C. univittatus, are known vectors of several arboviruses. Previous human cases of WNV have been putatively acquired in this region (Connell et al., 2004), followed by detection of WNV infected $C$. pipiens and C. univittatus in the same area (Esteves et al., 2005). A phylogenetic analysis strongly suggested a re-introduction of the virus, since it had first been detected in 1971 (Parreira et al., 2007). In fact, during the last decade WNV has been active in countries lining the Mediterranean (Morocco, Italy, France, Spain, and Greece; Zeller and Schuffenecker, 2004; Rossini et al., 2008; Barzon et al., 2009; Rizzo et al., 2009; Danis et al., 2011a,b). Despite the fact that no mosquito infections were detected in the present study, which may also be due to the small sample size, surveillance should be continued as all previous evidence support the idea that the Algarve, has the conditions for WNV re-mergence, and one of the species previously found infected, C. pipiens, is still the most abundant in several locations and is a known bridge vector, feeding both in birds and humans (Gomes et al., 2009).

\section{ACKNOWLEDGMENTS}

This work was funded by Project "RARIMOSQ" (ref. 35-60624-S), Fundação Calouste Gulbenkian, Portugal, and UPMM/FCT/MCTES Portugal.

\section{REFERENCES}

Almeida, A. P. G., Galão, R. P., Novo, M. T., Sousa, C. A., Parreira, R., Pinto, J., and Carvalho, L. (2005). Update on the distribution of some mosquito (Diptera: Culicidae) species in Portugal. Eur. Mosq. Bull. 19, 20-25.

Almeida, A. P. G., Galão, R. P., Sousa, C. A., Novo, M. T., Parreira, R., Pinto, J., Piedade, J., and Esteves, A. (2008). Potential mosquito vectors of arboviruses in Portugal: species, distribution, abundance and West Nile infection. Trans. R. Soc. Trop. Med. Hyg. 102, 823-832.

Barzon, L., Squarzon, L., Cattai, M., Franchin, E., Pagni, S., Cusinato, R., and Palu, G. (2009). West Nile virus infection in Veneto region, Italy, 2008-2009. Euro Surveill. 14, 19289.

CCDR. (2007). Plan for Improvement and Management of Humid Coastal Areas between Armação de Pêra and Ancão [Lagoon of Salgados,
Almargem, Dunas Douradas, Vale do Garrão (in Portuguese)]. Lisbon: AGRIPRO AMBIENTE, Consulting S. A. Comissão de Coordenação e Desenvolvimento Regional do Algarve.

CDC. (2011). Available at: http://www. cdc.gov/ncidod/dvbid/westnile/bird species.htm. [accessed March 2011].

Chaskopoulou, A., Dovas, C., Chaintoutis, S., Bouzalas, I., Ara, G., and Papanastassopoulou, M. (2011). Evidence of enzootic circulation of West Nile virus (Nea Santa-Greece-2010, lineage 2), Greece, May to July 2011. Euro Surveill. 16, 19933.

Connell, J., McKeown, P., Garvey, P., Cotter, S., Conway, A., O’Flanagan, D., O’Herlihy, B. P., Morgan, D., Nicoll, A., and Lloyd, G. (2004). Two linked cases of West Nile virus (WNV) acquired by Irish tourists in the Algarve, Portugal. Euro Surveill. $8,1-2$.
Danis, K., Papa, A., Theocharopoulos, G., Dougas, G., Athanasiou, M., Detsis, M., Baka, A., Lytras, T., Mellou, K., Bonovas, S., and Panagiotopoulos, T. (2011a). Outbreak of West Nile virus infection in Greece, 2010. Emerging Infect. Dis. 17, 1868-1872.

Danis, K., Papa, A., Papanikolaou, E., Dougas, G., Terzaki, I., Baka, A., Vrioni, G., Kapsimali, V., Tsakris, A., Kansouzidou, A., Tsiodras, S., Vakalis, N., Bonovas, S., and Kremastinou, J. (2011b). Ongoing outbreak of West Nile virus infection in humans, Greece, July to August 2011. Euro Surveill. 16, 19951.

Esteves, A., Almeida, A. P. G., Galão, R. P., Parreira, R., Piedade, J., Rodrigues, J., Sousa, C. A., and Novo, M. T. (2005). West Nile Virus in Southern Portugal, 2004. Vector Borne Zoonotic Dis. 5, 410-413.

Feith, H. (2007). Projeto Chegadas Relatório 2007. Lisboa: Sociedade Portuguesa para o Estudo das Aves.
Feith, H. (2010). Projeto Chegadas Relatório 2010. Lisboa: Sociedade Portuguesa para o Estudo das Aves.

Figuerola, J., Jimenez-Clavero, M. A., Lopez, G., Rubio, C., Soriguer, R., Gomez-Tejedor, C., and Tenorio, A. (2008). Size matters: West Nile virus neutralizing antibodies in resident and migratory birds in Spain. Vet. Microbiol. 132, 39-46.

Filipe, A. R. (1972). Isolation in Portugal of West Nile virus from Anopheles maculipennis mosquitoes. Acta Virol. 16, 361.

Formosinho, P., Santos-Silva, M. M., Santos, A., Melo, P., Encarnação, V., Santos, N., Nunes, T., Agrícola, R., and Portas, M. (2006). O vírus West Nile em Portugal - estudos de vigilância epidemiológica. Revista Portuguesa de Ciências Veterinárias 101, 557-558.

Gomes, B., Sousa, C., Novo, M., Freitas, F. B., Alves, R., Côrte-Real, A. R., Salgueiro, P., Donnelly, M. J., 
Almeida, A. P., and Pinto, J. (2009). Asymmetric introgression between sympatric molestus and pipiens forms of Culex pipiens (Diptera: Culicidae) in the Comporta region, Portugal. BMC Evol. Biol. 9, 262. doi:10.1186/1471-2148-9-262

Hayes, E. B., Komar, N., Nasci, S. R., Montgomery, S. P., O'Leary, D. R., and Campbell, G. L. (2005). Epidemiology and transmission dynamics of West Nile virus disease. Emerging Infect. Dis. 11, 1167-1173.

IM. (2010). Available at: http://www. meteo.pt/pt/oclima/normais/index. html?page $=$ normais_far.xml [accessed in 2010]

Jourdain, E., Gauthier-Clerc, M., Dominique, J. B., and Sabatier, P. (2007). Bird migration routes and risk for pathogen dispersion into Western Mediterranean Wetlands. Emerging Infect. Dis. 13, 365-372.

Kramer, L. D., Styer, L. M., and Ebel, G. D. (2008). A global perspective on the epidemiology of West Nile virus. Annu. Rev. Entomol. 53, 61-81.

Krisztalovics, K., Ferenczi, E., Molnár, Z., Csohán, Á., Bán, E., Zöldi, V., and Kaszás, K. (2008). West Nile virus infections in Hungary, AugustSeptember 2008. Euro Surveill. Euro Surveill. 13, 19030.

Linke, S., Niedrig, M., Kaiser, A., Ellerbrok, H., Muller, K., Muller, T., Conraths, F. J., Muhle, R.-U., Schmidt, D., Koppen, U., Bairlein, F., Berthold, P., and Pauli, G. (2007). Serologic evidence of West Nile virus infections in wild birds captured in Germany. Am. J. Trop. Med. Hyg. 77, 358-364.

Lundström, J. O. (1999). Mosquitoborne viruses in western Europe: a review. J. Vector Ecol. 24, 1081-1710.

Lysyk, T. J. (2010). Species abundance and seasonal activity of mosquitoes on cattle facilities in southern Alberta, Canada. J. Med. Entomol.47, 32-42.

Malkinson, M., Banet, C., Weisman, Y., Pokamunski, S., King, R., Drouet, M. T., and Deubel, V. (2002). Introduction of West Nile virus in the Middle East by migrating white storks. Emerging Infect. Dis. 8, 392-397.

Medlock, J. M., Snow, K. R., and Leach, S. (2006). Possible ecology and epidemiology of medically important mosquito-borne arboviruses in Great Britain. Epidemiol. Infect. 135, 466-482.

Morgan, D. (2006). Control of arbovirus infections by a coordinated response: West Nile virus in England and Wales. FEMS Immunol. Med. Microbiol. 48, 305-312.

Mouchet, J., Rageau, J., Laumond, C., Hannoun, C., Beytout, D., Oudar, J., Corniou, B., and Chippaux, A. (1970). Epidemiology of West Nile virus: study of a focus in Camargue. V. The vector: Culex modestus Ficalbi Diptera; Culicidae. Ann. Inst. Pasteur (Paris) 118, 839-855.

Murgue, B., Murri, S., Triki, H., Deubel, V., and Zeller, H. (2001). West Nile in the Mediterranean basin: 1950-2000. Ann. N. Y. Acad. Sci. 951, 117-126.

Newhouse, V. R., Chamberlain, R. W., Johnston, J. F., and Sudia, W. D. (1966). Use of dry ice to increase mosquito catches of the CDC miniature light trap. Mosq. News 26, 30-35.

Newton, A., Oliveira, P. S., Icely, J. D., and Foster, P. A. (2010). Monitoring of oxygen condition in the Ria Formosa coastal lagoon, Portugal. J. Environ. Monit. 12, 355-360.

Osório, H. C, Amaro, F., Zé-Zé, L., Moita, S., Labuda, M., and Alves, M. J. (2008). Species composition and dynamics of adult mosquitoes of southern Portugal. Eur. Mosq. Bull. $25,12-23$.

Parreira, R., Severino, P., Freitas, F., Piedade, J., Almeida, A. P. G., and Esteves, A. (2007). Two distinct introductions of the West Nile virus in Portugal disclosed by phylogenetic analysis of genomic sequences. Vector Borne Zoonotic Dis. 7, 344-352.

Ramos, H. C., Ribeiro, H., and Novo, M. T. (1992). Mosquito ecology in southeastern Portugal, an area receptive to African horse sickness. Bull. Soc. Vector Ecol. 17, 85-93.

Ramos, H. C., Ribeiro, H., Pires, C. A., and Capela, R. A. (1977/1978). Research on the mosquitoes of Portugal (Diptera, Culicidae) IIthe mosquitoes of Algarve. An. Inst. Hig. Med. Trop. (Lisb.) 5, 237-256.
Rappole, J. H., Derrickson, S. R., and Hubálek, Z. (2000). Migratory birds and spread of West Nile virus in the western Hemisphere. Emerging Infect. Dis. 6 319-328.

Rappole, J. H., and Hubálek, Z. (2003). Migratory birds and West Nile virus. J. Appl. Microbiol. 94, 47-58.

Ribeiro, H. (1967). A solidifiable formic acid-PVA solution for transporting, preserving and mounting mosquito larvae and pupae. Stain Technol. 42, 159-160.

Ribeiro, H., and Ramos, H. C. (1999). Identification keys of the mosquitoes of continental Portugal, Açores and Madeira. Eur. Mosq. Bull. 3, 1-11.

Ribeiro, H., Ramos, H. C., Capela, R. A. and Pires, C. A. (1980). Os Mosquitos de Cabo Verde (Diptera: Culicidae). Sistemática, Distribuição, Bioecologia e Importância Médica. Lisboa: Junta de investigações científicas do Ultramar. 139.

Rizzo, C., Vescio, F., Declich, S., Finarelli, A. C., Macini, P., Mattivi, A., Rossini, G., Piovesan, C., Barzon, L., Palù, G., Gobbi, F., Macchi, L., Pavan, A. Magurano, F., Ciufolini, M. G., Nicoletti, L., Salmaso, S., and Rezza, G. (2009). West Nile virus transmission with human cases in Italy, AugustSeptember 2009. Euro Surveill. 14, 19353.

Rossini, G., Cavrini, F., Pierro, A., Macini, P., Finarelli, A. C., Po, C., Peroni, G., Di Caro, A., Capobianchi, M., Nicoletti, L., Landini, M. P. and Sambri, V. (2008). First human case of West Nile virus neuroinvasive infection in Italy. Euro Surveill. 13, 19002.

Rydzanicz, K., and Lonc, E. (2003). Species composition and seasonal dynamics of mosquito larvae in the Wroclaw, Poland area. J. Vector Ecol. 28, 255-266.

Scaramozzino, N., Crane, J.-M., Jouan, A., DeBriel, A. D., Stoll, F., and Garin, D. (2001). Comparison of flavivirus universal primer pairs and development of a rapid, highly sensitive heminested reverse transcriptionPCR assay for detection of flaviviruses targeted to a conserved region of the NS5 gene sequences. J. Clin. Microbiol. 39, 1922-1927.
Smithburn, K. C., Hughes, T. P., Burke, A. W., and Paul, J. H. (1940). A neurotropic virus isolated from the blood of a native of Uganda. Am. J. Trop. Med. s1-s20, 471-492.

Southwood, T. R. E. (1978). Ecological Methods, 2nd Edn. London: Chapman and Hall, 524.

Sudia, W. D., and Chamberlain, R. W. (1962). Battery-operated light trap. An improved model. Mosq. News 22, 126-129.

Vázquez, A., Ruiz, S., Herrero, L., Moreno, J., Molero, F., Magallanes, A., Sánchez-Seco, M. P., Figuerola, J., and Tenorio, A. (2011). West Nile and Usutu viruses in mosquitoes in Spain, 2008-2009. Am. J. Trop. Med. Hyg. 85, 178-181.

White, D. J. (2001). Vector surveillance for West Nile virus. Ann. N. Y. Acad. Sci. 951, 74-83.

Zeller, H. G., and Schuffenecker, I. (2004). West Nile virus: an overview of its spread in Europe and the Mediterranean basin in contrast to its spread in the Americas. Eur. J. Clin. Microbiol. Infect. Dis. 23, 147-156.

Conflict of Interest Statement: The authors declare that the research was conducted in the absence of any commercial or financial relationships that could be construed as a potential conflict of interest.

Received: 17 October 2011; accepted: 27 December 2011; published online: $10 \mathrm{Jan}$ uary 2012.

Citation: Freitas FB, Novo MT, Esteves $A$ and de Almeida APG (2012) Species composition and WNV screening of mosquitoes from lagoons in a wetland area of the Algarve, Portugal. Front. Physio. 2:122. doi: 10.3389/fphys.2011.00122 This article was submitted to Frontiers in Systems Biology, a specialty of Frontiers in Physiology.

Copyright (C) 2012 Freitas, Novo, Esteves and de Almeida. This is an open-access article distributed under the terms of the Creative Commons Attribution Non Commercial License, which permits noncommercial use, distribution, and reproduction in other forums, provided the original authors and source are credited. 